\title{
Estimation of lateral capacity of rock socketed piles in layered soil-rock profile
}

\author{
A. R. Prakash and Kasinathan Muthukkumaran *
}

\section{${ }^{*}$ Correspondence:}

kmk@nitt.edu

Department of Civil

Engineering, National

Institute of Technology,

Tiruchirappalli 620015, India

\begin{abstract}
Large diameter rock socketed piles were preferred for the purpose of transmission of a huge volume of both vertical and lateral load from superstructure to a deeper depth safely without any structural defects. A series of experimental program was conducted on model pile for studying the behaviour of the rock socketed pile under static lateral load in a soil-rock layered profile system. The model piles were instrumented with displacement and force transducers for measuring the magnitude of the pile movement and load transferred by the pile. The experimental results showed that the rock socketed pile lateral capacity has significantly affected by the depth of embedment of the pile in soil and depth of rock socket. There was a considerable increase in the lateral capacity of the pile when the depth of socketing is three times the diameter of the pile into rock with a minimum embedment. In the $3 \mathrm{D}$ socketed piles, the lateral capacity of the pile is almost 18 times higher than the non-socketed piles. From the experimental study, it is also observed that when the piles socketed more in to the hard strata (rock), the depth of fixity increases and the lateral displacement reduces substantially.
\end{abstract}

Keywords: Socketed pile, Lateral capacity, Model pile, Pile instrumentation, Embedment depth and lateral deflection

\section{Introduction}

Heavy superstructures like bridge piers, elevated flyovers and offshore wind turbine structures supported by large diameter piles are often subjected to a significant amount of lateral loads. The lateral capacity of the pile mainly depends on the ultimate soil resistance and the stiffness of the pile. However, the deflection at the pile head should be within allowable limits under working load. Generally, large diameter piles were suggested for offshore wind farms and for heavy transmission towers in onshore in order to withstand the heavy loads from wind, waves, current and etc. In such a case, when the hard stratum is relatively in a shallow depth, the pile has to be socketed into the hard stratum to minimum depth of 1-3times the diameter (1D-3D) of pile based the compressive strength of the rock as per IS 14593-2003 [16]. Casting the pile in the hard stratum is a time-consuming process and requires heavy drilling equipment's for execution of the work, resulting in economic loss. However, the piles are expected to be supported by a considerable soil thickness before socketed into the hard stratum where the effect of soil embedment play a key role in the rock socketed pile capacity. Therefore, a systematic 
experimental study is needed to understand the impact of soil embedment and depth of rock socketing on lateral capacity of piles especially on intermediate piles.

Extensive research has been carried out by Broms [3], Prakash and Kumar [26], Gandhi and Selvam [8], Muthukkumaran et al. [21], Begum et al. [1], Chandrasekaran et al. [5], Muthukkumaran [22] and Deendayal et al. [7] theoretically and experimentally to study the behaviour of the pile on clayey and sandy soil under lateral load. A limited number of instrumented load tests have been conducted for studying the response of pile socketed onto rock strata subjected to lateral load. Firstly, Carter and Kulhawy [4] presented parametric solutions from which closed-form solutions may be derived for various loading conditions and rock stiffness for the estimation of lateral deflection. Further, Reese [27] presented a p-y curve method for the analysis of single pile socketed onto weak rock and subjected to lateral loading. The non-linearity of the rock mass surrounding was considered by assuming a series of springs of soil or rock along the length of the pile. Ke Yang [19] conducted two field tests on piles and suggested a new method of deriving experimental p-y curves from load test results based on curve fitting techniques and presented the comparison of the method to existing methods. However, the method application of the method is limited due to requirement of field test results. Liang et al. [20] presented hyperbolic p-y criterion is developed based on both theoretical derivations and empirical equations derived from numerical finite element parametric analysis results. Very few researchers have considered the layered soil-rock profile thickness in the study of the pile under lateral load. Zhang et al. [31] proposed a non-linear continuum method to predict the load-displacement response of rock-socketed drilled shafts under lateral loads by treating soil/rock as an elastoplastic material which was not widely adopted. Haberfield and Collingwood [10] introduced a method to provide significant improvements in pile design, in respect both to optimisation of socket lengths and to reduction of risk based on field observations. Jin-Jian Chen et al. [18] presented a method considering a non-uniform shaft with diameter and/or flexural rigidity changing with depth and embedded in multiple layers of soil/rock masses. The method considers not only the yielding of the soil/rock mass but also the decrease in flexural rigidity of the shaft due to cracking. Rezazadeh and Eslami [28] presented a comparison of existing empirical formulae for the prediction of lateral shaft resistance. Singh et al. [29] explored the performance of the rock-socketed pile under combined loading. However, the existing methods have not considered various paramters simultaneously such as the embedment depth in the soil, depth of socketing into the rock-strata and the behaviour of the pile. Therefore, there is a need for a comprehensive field and lab-scale experimental study for the validation of the existing methods of analysis. So, in this paper, the lateral response of socketed pile has been discussed by conducting a series of experiments on instrumented model piles through variation of its depth of socketing up to 3D with an increasing order of 0.5D ( $D$ is diameter of pile) and increase in the $\left(L_{e} / L\right)$ ratio, where $L_{e}$ is depth of embedment and $L$ is total length of pile with which the behaviour of the pile varies from short rigid to long flexible. Therefore, presenting a complete understanding of the behaviour of rock-socketed piles subjected to lateral loading. Nandhagopal and Muthukkumaran [24] studied the effect of rock-socketing on laterally loaded piles installed in the proximity of sloping ground and reported that the effect of socketing is most significant on the piles situated on the slope than the piles on the embankment. 


\section{Experimental program Testing chamber}

A test tank of size $2 \times 1 \times 1 \mathrm{~m}$ (length $\times$ width $\times$ height) made of $5 \mathrm{~mm}$ thick sheet of mild steel was fabricated to facilitate lateral load on socketed model pile without any boundary effect as presented by Begum et al. [1], Begum and Muthukkumaran [2] and Muthukkumaran and Begum [23]. Calculations for fixing the dimensions of the tank were based on the Rankine's theory and zone of influence of the pile by knowing the depth of fixity zf as suggested by Davisson and Robinson [6],

Depth of point of fixity, $\mathrm{z}_{\mathrm{f}}=1.8 \mathrm{~T}$

$$
\mathrm{T}=\sqrt[5]{\frac{\mathrm{EI}}{\eta_{\mathrm{h}}}}
$$

$\eta_{\mathrm{h}}=$ coefficient of modulus of subgrade reaction. The value of coefficient of horizontal modulus of subgrade reaction ' $\eta_{h}$ ' for sand (according to [30] is $2.5 \mathrm{MN} / \mathrm{m}^{3}$ for loose sand. The minimum length of the test tank estimated for relative density of loose sand is $678 \mathrm{~mm}$. Therefore, the tank dimensions selected are well clear of the boundary limitations. Figure 1 shows the isometric and photographical view of the test tank with installed model pile with a reaction frame of capacity 5 ton used to holding the actuator in position.

\section{Soil sample description}

The soil used for the experimental study was collected from River Cauvery, Trichy, India which is classified as poorly graded sand (SP) as per IS 1498-2002 [11]. The soil sample has an average particle $\left(D_{50}\right)$ size of $0.43 \mathrm{~mm}$ with an effective diameter $\left(D_{10}\right)$ of $0.2 \mathrm{~mm}$. The gradation chart for the collected sand is shown in Fig. 2. The River sand has uniform silica sand, with a coefficient of uniformity $C_{u}=2.5$ and coefficient of curvature $C_{c}=1.16$ with subangular particles as per IS 2720 (Part-4)-2006 [13]. The maximum $\left(\rho_{\max }\right)$ and minimum $\left(\rho_{\min }\right)$ dry densities of sand were obtained as per IS 2720-(Part-14)-2002 [15] and found to be $19.1 \mathrm{kN} / \mathrm{m}^{3}$ and $14.9 \mathrm{kN} / \mathrm{m}^{3}$ respectively. The direct shear test was conducted as per IS 2720-(Part-13)-2002 [14] and the angle of internal friction $(\phi)$ found to be $34.6^{\circ}$. The specific gravity of soil sample was found to be 2.62 as per IS 2720-(Part-3/Sec-1)-2002 [12].

Throughout the entire experimental programme, the soil sample was filled in the tank with a constant relative density of $R_{D}=30 \%$ (loose state) using the sand raining technique adopted by Muthukkumaran and Begum [23] and Muthukkumaran [22]. The relative density test was conducted as per IS 2720-(Part-13) for calibrating the sand raining device. Figure 3 shows relative density variation with height of fall. In order to maintain the loose state relative density (relative density $30 \%$ ) at the ground level, the height of fall of the sand raining device was maintained as $5.0 \mathrm{~cm}$.

\section{Model pile}

Three model piles were chosen with different diameters of $25.4 \mathrm{~mm}, 38.1 \mathrm{~mm}$ and $50.8 \mathrm{~mm}$ with $3 \mathrm{~mm}$ thickness and $1200 \mathrm{~mm}$ length each. The model piles were made of hollow aluminium pipe of having Young's modulus of $70 \mathrm{GPa}$. 


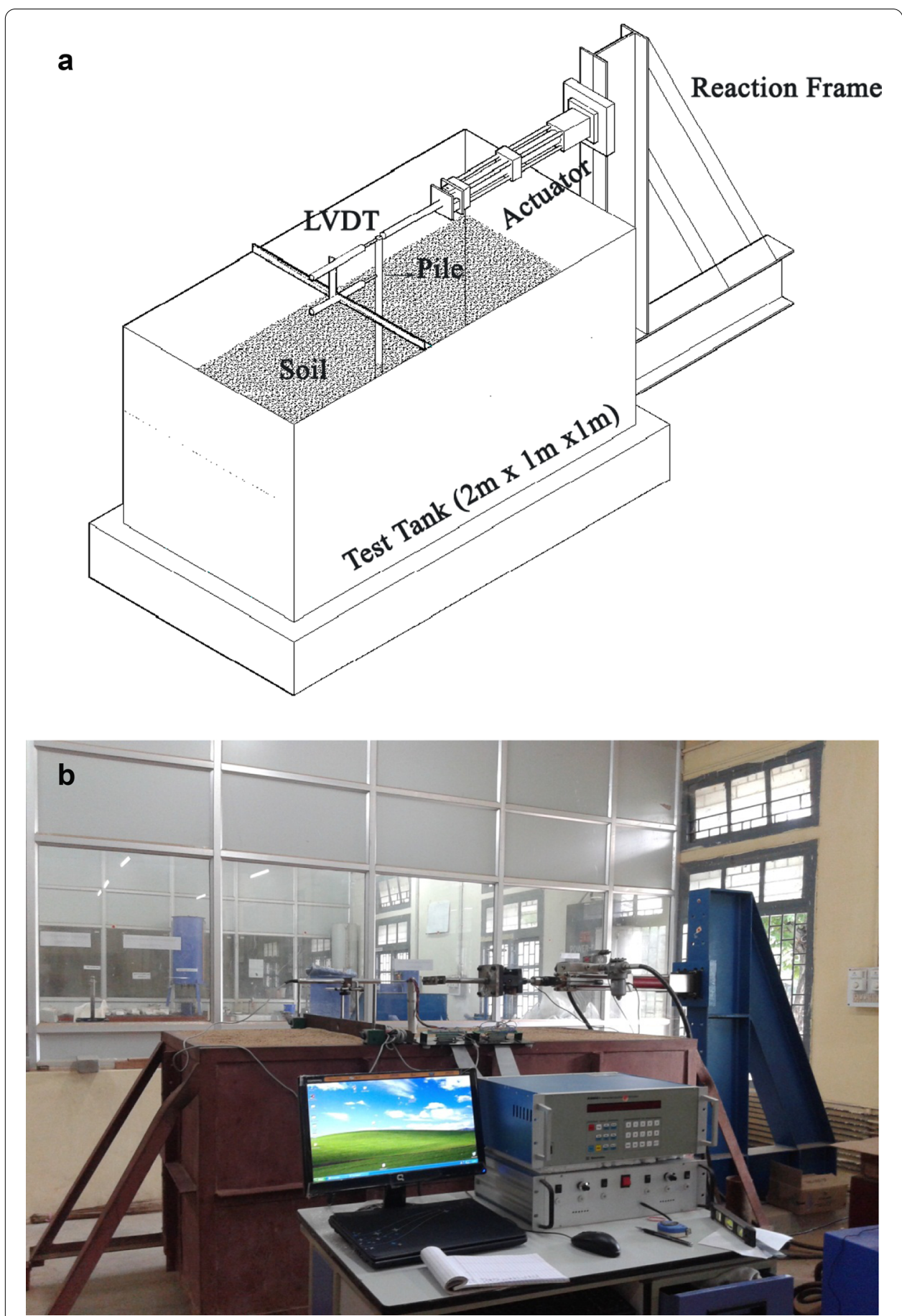

Fig. 1 Experimental setup. a Isometric view. b Photographic view

The scaling laws expressions for the flexural rigidity of the pile (EI), applied lateral load (F), loading eccentricity $\left(L_{f}\right)$, modulus of subgrade reaction $\left(\eta_{h}\right)$ and pile deflection $(y)$ have been derived based on Buckingham Pi theorem and presented below.

$$
(\mathrm{EI})_{\mathrm{p}}=\mathrm{c}_{1}^{5} * \mathrm{c}_{2}^{1} *(\mathrm{EI})_{\mathrm{m}}
$$




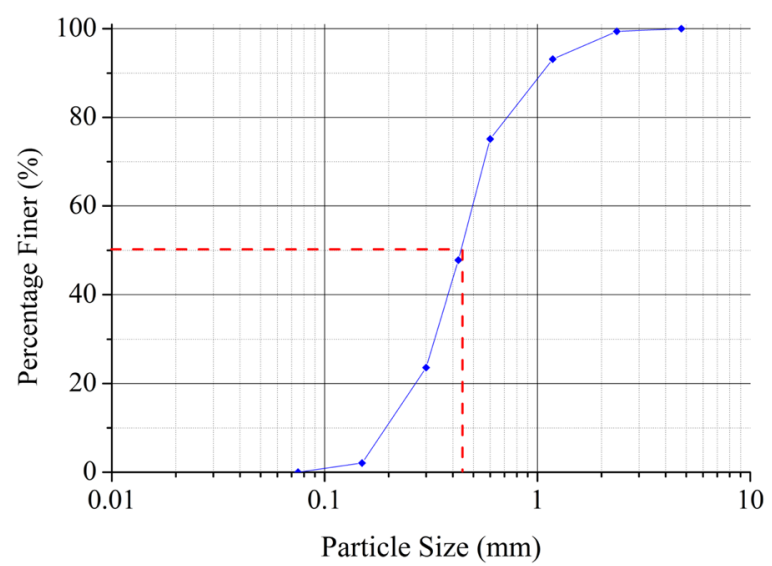

Fig. 2 Particle size classification

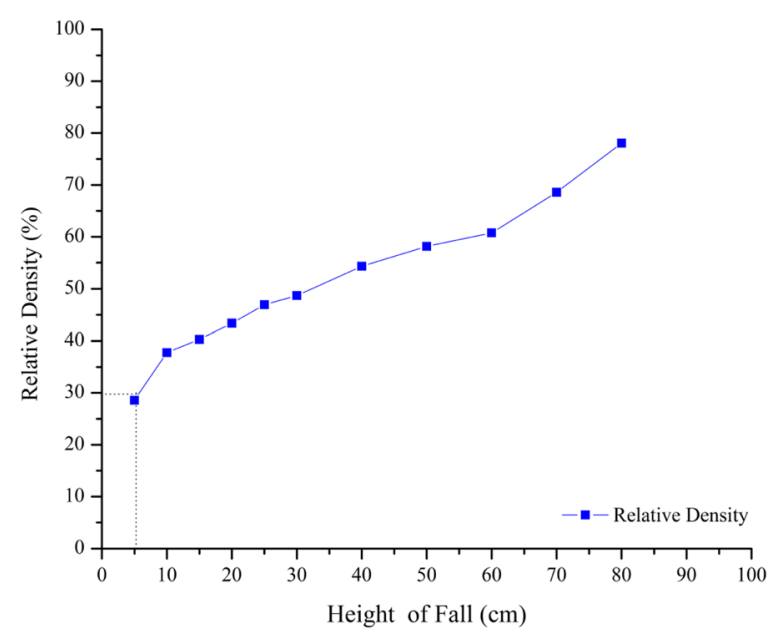

Fig. 3 Calibration of sand raining device

$$
\mathrm{F}_{\mathrm{p}}=\mathrm{c}_{1}^{3} * \mathrm{c}_{2}^{1} * \mathrm{~F}_{\mathrm{m}}
$$

$$
\eta_{\mathrm{hp}}=\mathrm{c}_{2}^{1} * \eta_{\mathrm{hm}}
$$

$$
\left(\frac{\mathrm{L}_{\mathrm{e}}}{\mathrm{D}}\right)_{\mathrm{p}}=\left(\frac{\mathrm{L}_{\mathrm{e}}}{\mathrm{D}}\right)_{\mathrm{m}}
$$

$$
\left(\frac{L_{f}}{D}\right)_{p}=\left(\frac{L_{f}}{D}\right)_{m}
$$

$$
\left(\frac{\mathrm{L}_{\mathrm{s}}}{\mathrm{D}}\right)_{\mathrm{p}}=\left(\frac{\mathrm{L}_{\mathrm{s}}}{\mathrm{D}}\right)_{\mathrm{m}}
$$


where, $\mathrm{c}_{1}$ and $\mathrm{c}_{2}$ are the scaling factors related to the pile diameter and unit weight of the soil such that $D_{p}=c_{1} * D_{m}$ and $\gamma_{p}=c_{2} * \gamma_{m}$. The unit weight does not vary between the test conditions and the field conditions and therefore, $\mathrm{c}_{2}$ is unity. The suffixes ' $p$ ' and ' $m$ ' given to the variables corresponds to the prototype and model conditions respectively. Assuming a scale factor of 20, the model piles shall represent a range of prototype piles of diameter $500 \mathrm{~mm}$ to $1025 \mathrm{~mm}$. The modelling of model tests was done considering $\mathrm{D} / \mathrm{d}_{50}$ greater than 45 such that there is no significant grain-size effect [9] and [25].

\section{Model pile installation}

The model pile was installed as a pre-installed pile (like cast-in-situ pile) at a particular location before pouring the sand. The verticality of the pile was checked before filling the soil as well the verticality was ensured at each stage of sand filling. Temporary clamps were used for holding the pile in position and removed while the load was applied. The sand was filled to the desired level with density index of $R_{D}=30 \%$ throughout the experimental program with the help of a sand raining device. A geo-gauge device was used to ensure the density of sand at a regular interval of height in the test tank.

\section{Depth of rock socketing}

The depth of socketing was achieved by grouting a concrete layer around the model pile to the required depth. In order to achieve moderately weathered rock socketed behaviour, a concrete mix of $\mathrm{M}_{50}$ was used. The grouting of concrete was done carefully in order to achieve the homogeneity. The pile is socketed at the center of a concrete plug with equal length and breadth which was $600 \mathrm{~mm}$. The thickness of the plug was provided as per the required depth of socketing which ranges between 0.5 to 3 times the pile diameter. The compressive strength and modulus of elasticity of the concrete were also estimated based on compression tests and found to be $50 \mathrm{~N} / \mathrm{mm}^{2}$ and 35,503.81 N/ $\mathrm{mm}^{2}$ respectively which lies within the range of moderately weathered rock conditions $\left(E_{\text {rock }}=20,000\right.$ to $\left.40,000 \mathrm{~N} / \mathrm{mm}^{2}\right)$.

\section{Test program}

Lateral load tests were conducted by a displacement controlled actuator of capacity $10 \mathrm{kN}$. The load was applied at the pile head level. Linearly varying differential transducers (LVDT) of travel length $50 \mathrm{~mm}$ with accuracy of $0.01 \mathrm{~mm}$ were placed at pile head and at the ground level for measuring the magnitude of the pile lateral movement. The rate of load increment was maintained as $0.01 \mathrm{~mm} / \mathrm{sec}$ and resistance to deformation of pile head was measured with the help of load cell attached to the actuator of accuracy $0.01 \mathrm{~N}$. The load was applied until the measured ground level deflection was greater than $4 \mathrm{~mm}$ for all the cases as per IS 14593-2003 [16]. The reading from LVDT and load cell were recorded for every $3 \mathrm{~s}$ with the help of the computer controlled Data Acquisition System. The torsional rotation and vertical movement of the pile head was measured with the help of torque transducer, LVDT respectively and found to be negligible for all the cases.

A total of 84 set of experiments were carried out by varying the length of depth of embedment to total length of the pile $\left(\mathrm{L}_{\mathrm{e}} / \mathrm{L}\right)$ as $0.83,0.67,0.5$ and 0.33 , where the length of the pile was kept as constant and pile diameter changed. Similarly, the socketed depth 
was increased at an equal interval of $0.5 \mathrm{D}$ (diameter of the pile). The tests were also done on non-socketed pile with different $\mathrm{L}_{\mathrm{e}} / \mathrm{L}$ ratios for better comparison.

\section{Result and discussion}

\section{Classification of model piles}

The ultimate lateral resistance of the pile mainly depends on pile response against the applied lateral load. The pile response can be classified [3] on the basis of the soil subgrade reaction and the flexural stiffness (EI) of the pile. Unsaturated cohesionless sand has been used in the present study,where soil modulus linearly varies with depth and minimum at the ground level. The piles were classified in accordance to IS 2911 (Part 1/ Sec 4) -2010 [17], where the piles are considered long (elastic) when $L \geq 4 T$ and short (rigid) when $L \leq 2 T$. Where, $\mathrm{T}=$ Stiffness factor was obtained using Eq. 2 . The values of coefficient of subgrade reaction was taken as per Terzaghi [30], corresponding to sand in loose condition.

The behaviour of the pile in every case has been presented in Table 1. From the table, the pile having minimum free standing height of $200 \mathrm{~mm}\left(\mathrm{~L}_{\mathrm{e}}-1000 \mathrm{~mm}\right)$ and diameter of $25.4 \mathrm{~mm}$ will be behaving as a long flexible pile. The pile of $38.1 \mathrm{~mm}$ diameter with depth of socketing greater than 1D having $\left(\mathrm{L}_{\mathrm{e}}-600 \mathrm{~mm}\right)$ and pile of 25.4, 38.1 and $50.8 \mathrm{~mm}$ diameter pile with $\mathrm{L}_{\mathrm{e}}-400 \mathrm{~mm}$ behave as a short rigid pile. The remaining model piles may be expected to behave as intermediate piles.

\section{Lateral load deflection response}

The lateral load capacity of the pile is estimated based on the deflection at the ground level. Therefore, the developed lateral deflection at the ground level vs. lateral load curves for $50.8 \mathrm{~mm}$ diameter pile with varying length of embedded pile in soil and varying socketed depths in rock (concrete) have been presented in Figs. 4, 5, 6, and 7. From the figures, it can be observed that the increase in depth of socketing into a hard stratum results in decreasing the pile head deflection and increase in the lateral load carrying capacity of pile all the piles. In case of $L_{e}=1000 \mathrm{~mm}$ as shown in Fig. 4, for an applied load of $50 \mathrm{~N}$ (at lower loading condition) ground level deflection decreased by $12 \%, 14 \%, 16 \%, 23 \%, 40 \%$ and $62 \%$ for increasing depth of socketing of $0.5 \mathrm{D}, 1 \mathrm{D}, 1.5 \mathrm{D}, 2 \mathrm{D}, 2.5 \mathrm{D}$ and 3D respectively, compared to a pile without socketing (WoS). For $\mathrm{L}_{\mathrm{e}} 600 \mathrm{~mm}$ (Fig. 6), lateral deflection is reduced by 118\%, 145\%, 166\%,

Table 1 Experimental model pile behaviour

\begin{tabular}{|c|c|c|c|c|c|c|c|c|c|c|c|c|}
\hline Pile diameter D (mm) & 25.4 & 38.1 & 50.8 & 25.4 & 38.1 & 50.8 & 25.4 & 38.1 & 50.8 & 25.4 & 38.1 & 50.8 \\
\hline Free Standing Height $L_{e}(\mathrm{~mm})$ & 200 & & & 400 & & & 600 & & & 800 & & \\
\hline WoS & $L P$ & IP & IP & $\mathbb{P}$ & IP & IP & $\mathbb{I P}$ & IP & SP & SP & SP & SP \\
\hline $0.5 \mathrm{D}$ & $L P$ & IP & IP & IP & $\mathbb{I P}$ & IP & IP & $\mathbb{P}$ & SP & $\mathrm{SP}$ & SP & SP \\
\hline 1D & LP & IP & $\mathbb{P}$ & IP & IP & IP & IP & SP & SP & SP & $\mathrm{SP}$ & SP \\
\hline $1.5 \mathrm{D}$ & $L P$ & IP & IP & IP & IP & IP & IP & SP & SP & SP & $\mathrm{SP}$ & SP \\
\hline $2 \mathrm{D}$ & LP & IP & $\mathbb{I P}$ & $\mathbb{I P}$ & $\mathbb{I P}$ & IP & IP & SP & SP & SP & SP & SP \\
\hline $2.5 \mathrm{D}$ & $L P$ & IP & $\mathbb{I P}$ & IP & $\mathbb{P}$ & $\mathbb{I P}$ & IP & SP & $\mathrm{SP}$ & $\mathrm{SP}$ & $\mathrm{SP}$ & SP \\
\hline $3 \mathrm{D}$ & $L P$ & $\mathbb{I P}$ & $\mathbb{I P}$ & $\mathbb{I P}$ & IP & $\mathbb{I P}$ & $\mathbb{I P}$ & SP & SP & SP & SP & SP \\
\hline
\end{tabular}

LP Long flexible pile, IP intermediate pile, SP short rigid pile, $D$ diameter of pile, WoS without Socketing 


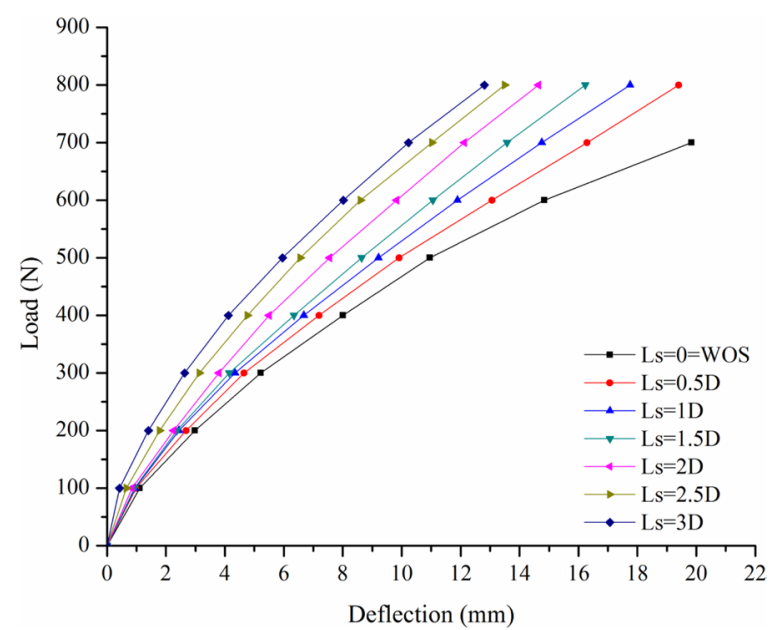

Fig. 4 Lateral load defection behavoiur of $50.8 \mathrm{~mm}$ diameter pile with embedded depth of $1000 \mathrm{~mm}$ $\left(\mathrm{L}_{\mathrm{e}}=1000 \mathrm{~mm}\right)$

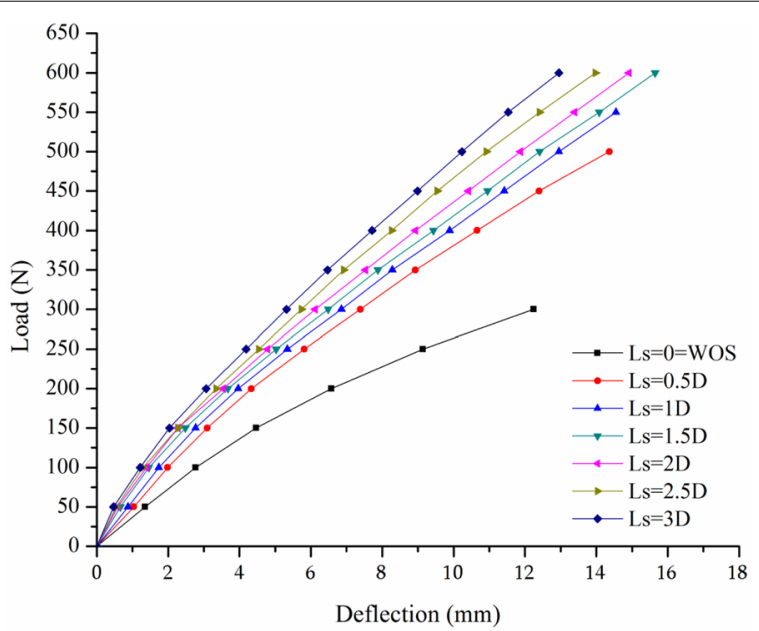

Fig. 5 Lateral load defection behavoiur of $50.8 \mathrm{~mm}$ diameter pile with embedded depth of $800 \mathrm{~mm}$ $\left(\mathrm{L}_{\mathrm{e}}=800 \mathrm{~mm}\right)$

$190 \%, 203 \%$ and $221 \%$ for increasing depths of socketing of $0.5 \mathrm{D}, 1 \mathrm{D}, 1.5 \mathrm{D}, 2 \mathrm{D}, 2.5 \mathrm{D}$ and 3D respectively. For $\mathrm{L}_{\mathrm{e}} 400 \mathrm{~mm}$ (Fig. 7), lateral deflection is reduced by $660 \%$, $921 \%, 934 \%, 936 \%, 942.06 \%$ and $982 \%$ for increasing depths of socketing of $0.5 \mathrm{D}, 1 \mathrm{D}$, 1.5D, 2D, 2.5D and 3D respectively. It can be observed for pile diameter $50.8 \mathrm{~mm}$ having EI of $9.042 \mathrm{kN} / \mathrm{m}^{2}$, the effect of depth of socketing has a greater effect from $0.5 \mathrm{D}$ onwards on pile head deflection. This is due to the increase in stiffness of the pile and short rigid pile behaviour. It can also be observed from the values that the depth of socketing in hard stratum has insignificant effect on the pile head deflection when the pile has maximum depth of pile embedment of $1000 \mathrm{~mm}\left(\mathrm{~L}_{\mathrm{e}}-1000 \mathrm{~mm}\right)$ whereas, the lateral deflection is moderately significant for lesser depth of embedment $\left(\mathrm{L}_{\mathrm{e}}-800\right.$, 600 and $400 \mathrm{~mm}$ ) in sand. A similar trend was observed in $25.4 \mathrm{~mm}$ and $38.1 \mathrm{~mm}$ 


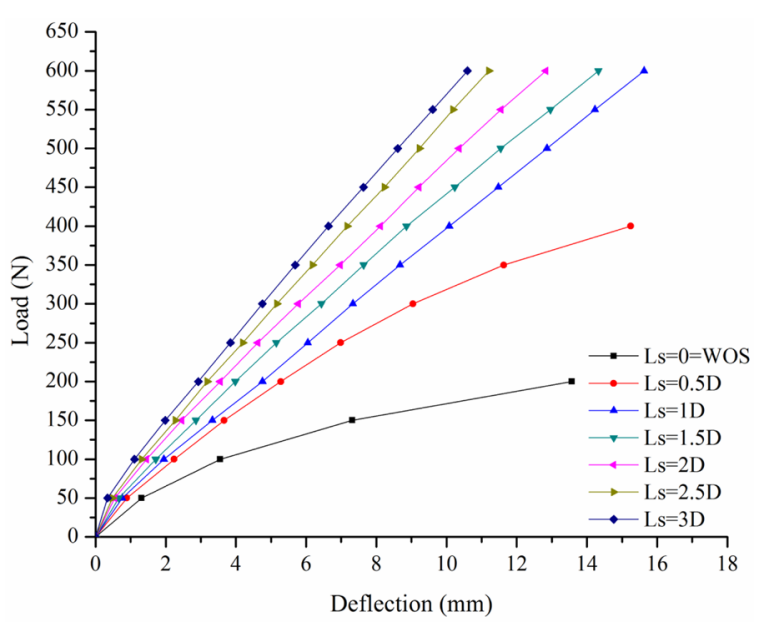

Fig. 6 Lateral load defection behavoiur of $50.8 \mathrm{~mm}$ diameter pile with embedded depth of $600 \mathrm{~mm}$ $\left(\mathrm{L}_{\mathrm{e}}=600 \mathrm{~mm}\right)$

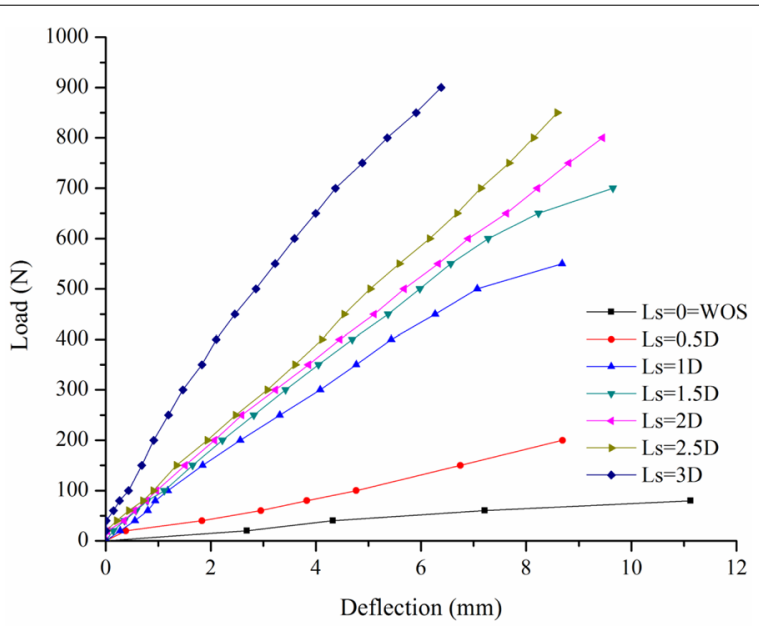

Fig. 7 Lateral load defection behavoiur of $50.8 \mathrm{~mm}$ diameter pile with embedded depth of $400 \mathrm{~mm}$ $\left(\mathrm{L}_{\mathrm{e}}=400 \mathrm{~mm}\right)$

diameter piles. But, in case of $25.4 \mathrm{~mm}$ diameter pile with $E I=0.944 \mathrm{kN} / \mathrm{m}^{2}$ flexural rigidity and $\mathrm{L}_{\mathrm{e}} 1000 \mathrm{~mm}$ above the ground level. In this case, for an applied load of $50 \mathrm{~N}$ the ground level deflection decreased by $23 \%, 29 \%, 33 \%, 36 \%$ and $52 \%$ for increased depth of socketing of $0.5 \mathrm{D}, 1 \mathrm{D}, 1.5 \mathrm{D}, 2 \mathrm{D}, 2.5 \mathrm{D}$ and $3 \mathrm{D}$ respectively, when compared to a pile without socketing condition (WoS) which is greater reduction that compared to the $50.8 \mathrm{~mm}$ diameter pile. This can be attributed to the long flexible behaviour of pile and greater passive resistance offered by the overlying soil. Therefore, in long flexible piles, the effect of rock socketing is almost negligible in the lateral response and hence socketing may not be needed.

In the case of $38.1 \mathrm{~mm}$ diameter pile with $\mathrm{EI}$ of $3.592 \mathrm{kN} / \mathrm{m}^{2}$ of which most cases fall under intermediate pile behaviour, the reduction in lateral pile head deflection due 
to the effect of depth of socketing was observed to be less significant up to a depth of socketing of $1 \mathrm{D}$ and greater effect for 1.5D to 3D depth of socketing at all embedment depths. To quantify, $\mathrm{L}_{\mathrm{e}} 1000 \mathrm{~mm}$ above ground level. In this case, for an applied load of $50 \mathrm{~N}$, ground level deflection is reduced by $18 \%, 30 \%, 46 \%, 50 \%, 56 \%$ and $72 \%$ for increasing depths of socketing of $0.5 \mathrm{D}, 1 \mathrm{D}, 1.5 \mathrm{D}, 2 \mathrm{D}, 2.5 \mathrm{D}$ and $3 \mathrm{D}$ respectively, compared to a pile without socketing (WoS). For $\mathrm{L}_{\mathrm{e}} 400 \mathrm{~mm}$, the ground level lateral deflection is reduced by $264 \%, 480 \%, 559 \%, 595 \%, 621 \%$ and $650 \%$ for increasing depths of socketing of $0.5 \mathrm{D}, 1 \mathrm{D}, 1.5 \mathrm{D}, 2 \mathrm{D}, 2.5 \mathrm{D}$ and $3 \mathrm{D}$ respectively.

\section{Lateral capacity of socketed pile}

Estimation of the safe lateral load for socketed pile was estimated as per IS 14593-2003 [16]. As per codel recommendation, the safe load for socketed pile is the minimum of the load corresponding to $4 \mathrm{~mm}$ deflection or $50 \%$ final load at which the total displacement of $8 \mathrm{~mm}$. Figures $8,9,10$, and 11 show the measured safe load for all three pile diameters with increase in depth of socketing $\left(\mathrm{L}_{\mathrm{s}}\right)$ corresponding to $4 \mathrm{~mm}$ deflection at ground level. From the results presented in these figures, it is very clearly seen that, the depth of embedment play a major role in the pile capacity irrespective of the depth of socketing. That is, the influence of depth of socketing can be observed to have an insignificant effect on lateral capacity of small diameter piles $(D=25.4 \mathrm{~mm})$ whereas the depth of socketing is significantly increases lateral pile capacity in large diameter piles $(D=38.1 \& 50.8 \mathrm{~mm})$ in cases of lower depth of embedment. This effect can be clearly observed in Fig. 11, where depth of embedment is minimum $\left(\mathrm{L}_{\mathrm{e}}=400 \mathrm{~mm}\right)$. To quantify, at $\mathrm{L}_{\mathrm{e}} 400 \mathrm{~mm}$, the lateral capacity of the $25.4 \mathrm{~mm}$ pile increases only by $1.29,1.47,1.56,1.65,2.12$, and 2.35 times lateral capacity times the capacity of without socketed pile with increase in depth of socketing from $0.5 \mathrm{D}$ to $3 \mathrm{D}$. Whereas, the $38.1 \mathrm{~mm}$ pile improves by $1.33,2.33,4.33,6.00,6.67$ and 10.67 times the capacity of without socketed pile and the lateral capacity of $50.8 \mathrm{~mm}$ diameter pile increases by 2.57, 7.57, 9.14, 9.71, 11.29 and 18.86 times the capacity of without socketed pile for $0.5 \mathrm{D}, 1 \mathrm{D}, 1.5 \mathrm{D}, 2 \mathrm{D}, 2.5 \mathrm{D}$, and $3 \mathrm{D}$ depth of socketing cases respectively. From this observation, it is very clear that the socketing depth is having a significant improvement of

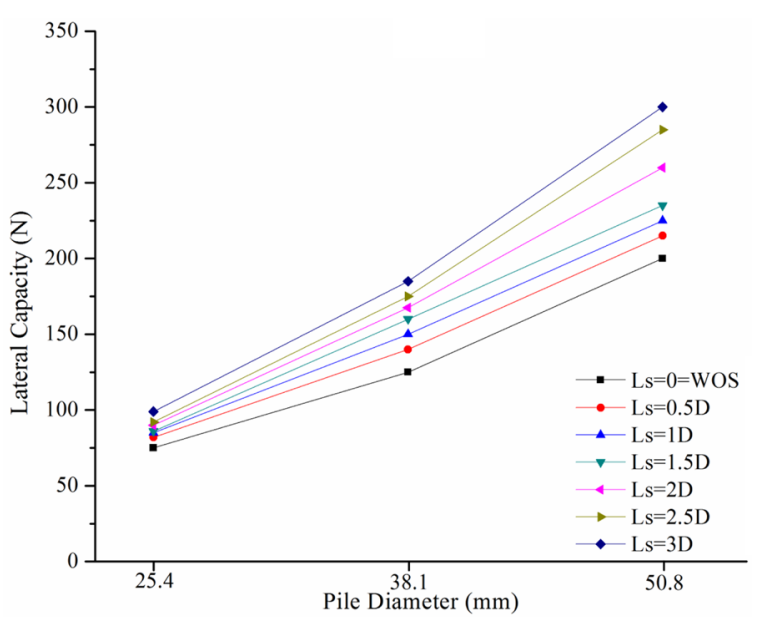

Fig. 8 Lateral capacity of pile with varying depth of socketing for pile having embedded depth $L_{e} 1000 \mathrm{~mm}$ 


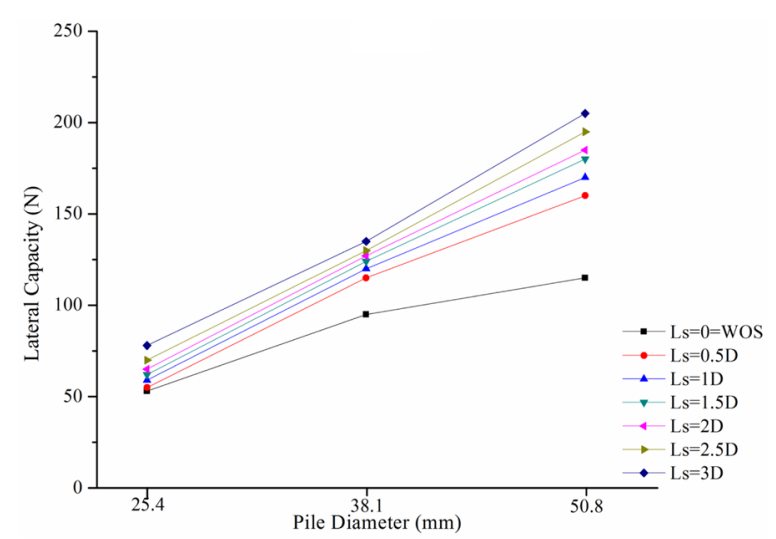

Fig. 9 Lateral capacity of pile with varying depth of socketing for pile having embedded depth $L_{e} 800 \mathrm{~mm}$

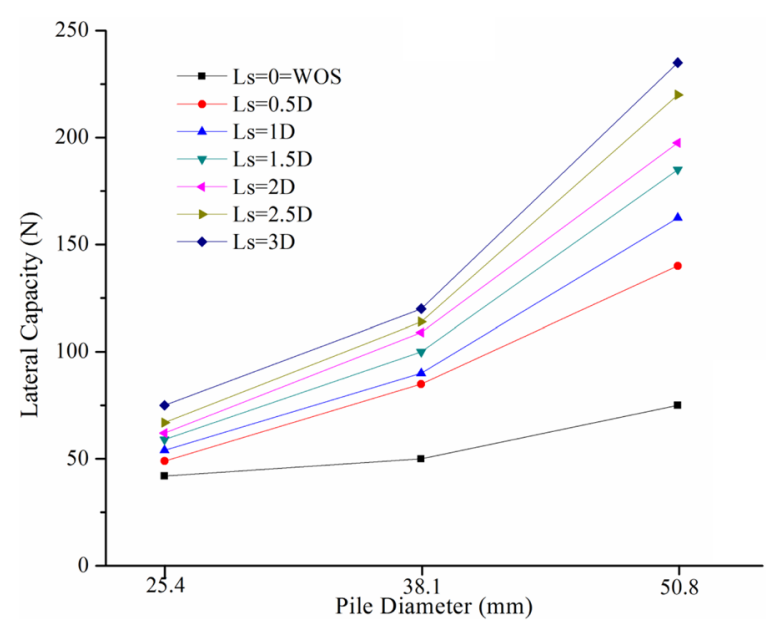

Fig. 10 Lateral capacity of pile with varying depth of socketing for pile having embedded depth $L_{e} 600 \mathrm{~mm}$

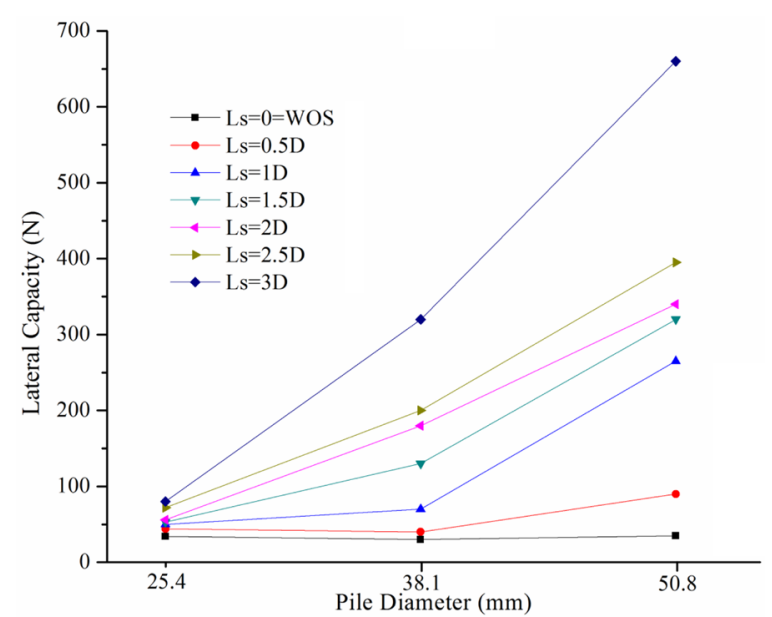

Fig. 11 Lateral capacity of pile with varying depth of socketing for pile having embedded depth $\mathrm{L}_{e} 400 \mathrm{~mm}$ 
lateral load capacity on short piles. This is may be due the enhanced relative stiffness of the soil-pile-rock system in short piles.

On the other hand, from Fig. 8, where the embedded length of the pile is maximum at $\mathrm{L}_{\mathrm{e}}=1000 \mathrm{~mm}$, the effect of socketing does not appear to be very significant in most cases. Numerically, at maximum embedded depth of $\mathrm{L}_{\mathrm{e}} 1000 \mathrm{~mm}$, the lateral load capacity of $25.4 \mathrm{~mm}$ diameter pile increases linearly with increase in depth of socketing and it increases by $1.09,1.13,1.15,1.20,1.23$ and 1.32 times the load carrying capacity of the without socketed pile. Whereas, the load carrying capacity of the $38.1 \mathrm{~mm}$ diameter pile increases by $1.12,1.20,1.28,1.34,1.40$ and 1.48 times the load carrying capacity of the without socketed pile. Also, under identical conditions the load carrying capacity of the $50.8 \mathrm{~mm}$ diameter pile improves by $1.08,1.13,1.18,1.30,1.43$ and 1.50 times. This can again be attributed to the long flexible behaviour of pile and greater passive resistance offered by the overlying soil.

The magnitude of lateral capacity gradually increases with increase in the depth of socketing and pile diameter for all $\mathrm{L}_{\mathrm{e}} / \mathrm{L}$ ratios. However, in greater $\mathrm{L}_{\mathrm{e}} / \mathrm{L}(0.83 \& 0.67)$ piles, the depth of socketing made slight difference in lateral capacity as shown in Figs. 8 and 9. Figure 10 shows an exponential increase in the load capacity with increase in depth of socketing for Le/L of 0.5, which can be attributed to the resistance offered by hard stratum (socketed depth). For the case Le/L of 0.33, where the embedded depth in soil is minimum (Le-400 mm) as shown in Fig. 11, the influence of subgrade reaction of hard stratum is maximum resulting in load carrying capacity increasing dramatically with increase in depth of socketing.

\section{Expression for lateral load capacity of socketed pile}

Although, the improvements in lateral capacity were comparatively insignificant in cases of piles with greater $\mathrm{L}_{\mathrm{e}} / \mathrm{L}$ ratio, the experimental results showed the effect of socketing depth $\left(\mathrm{L}_{\mathrm{s}}\right)$ had an influence on lateral load capacity of all three diameter piles in all cases. For a minimum embedment depth of pile in soil $\left(\mathrm{L}_{\mathrm{e}}-400 \mathrm{~mm}\right)$ and maximum depth of socket $\left(\mathrm{L}_{\mathrm{s}}-3 \mathrm{D}\right)$, the pile capacity dramatically increased 18.86 times the capacity of pile without socketing.

For a pile having $\mathrm{L}_{\mathrm{e}}=600$ and $\mathrm{L}_{\mathrm{e}}=800 \mathrm{~mm}$, the lateral capacity increases with increase in depth of socketing linearly with an incremental order of 0.2 times the capacity of pile without socketing, except in the case of a pile having a diameter $50.8 \mathrm{~mm}$ and depth of socketing 3D. Based on the experimental results, empirical equations were proposed by multi regression analysis for estimating the allowable lateral load $\left(\mathrm{P}_{\mathrm{a}}\right)$ on socketed. The experimentally obtained pile capacity for each case of the test was taken as dependent variable and the ratio of depth of embedment of pile in soil to the diameter of pile $\left(L_{e} / D\right)$, the ratio of the length of free standing height to the diameter of pile $\left(\mathrm{L}_{\mathrm{f}} / \mathrm{D}\right)$ and ratio of length of socket depth to diameter of pile $\left(\mathrm{L}_{\mathrm{s}} / \mathrm{D}\right)$ were considered as independent variable for the multi regression analysis. From the analysis, it is observed that the pile capacity bi-linearly varying with respect to $\left(\mathrm{L}_{\mathrm{e}} / \mathrm{D}\right),\left(\mathrm{L}_{\mathrm{f}} / \mathrm{D}\right)$ and $\left(\mathrm{L}_{\mathrm{s}} / \mathrm{D}\right)$. Therefore, two sets of equations are proposed with respect to $\mathrm{L}_{\mathrm{e}} / \mathrm{L}$ ratio.

$$
\mathrm{P}_{\mathrm{a}}=3.95\left(\mathrm{~L}_{\mathrm{e}} / \mathrm{D}\right)+3.78\left(\mathrm{~L}_{\mathrm{f}} / \mathrm{D}\right)-119.43\left(\mathrm{~L}_{\mathrm{s}} / \mathrm{D}\right) \quad \text { For } \mathrm{L}_{\mathrm{e}} / \mathrm{L}>0.3
$$




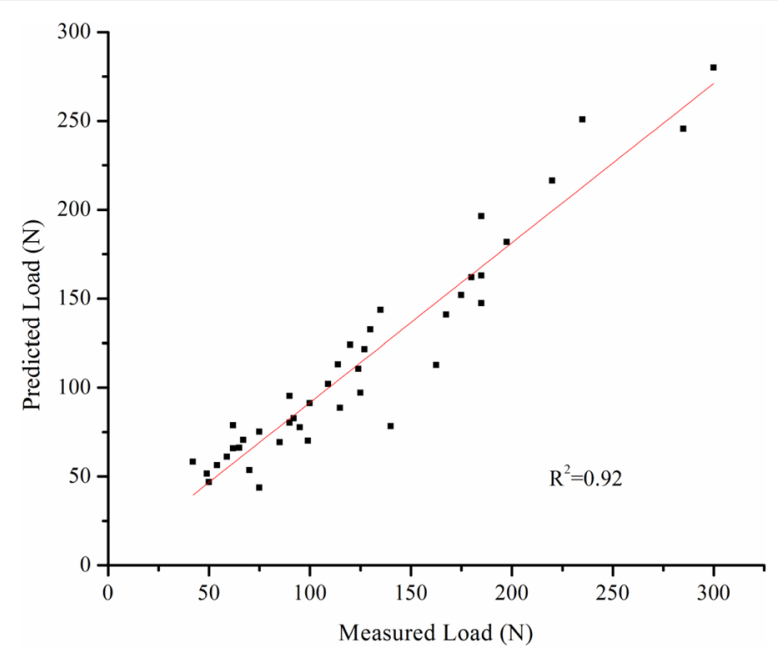

Fig. 12 Scatter plot for Le/L greater than 0.30

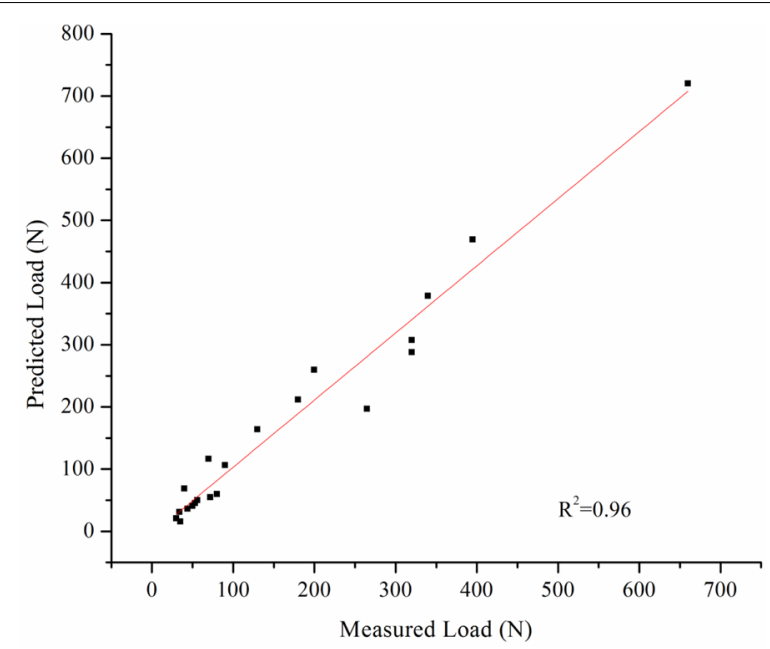

Fig. 13 Scatter plot for $L_{e} / L$ less than 0.30

$$
\mathrm{P}_{\mathrm{a}}=1.98\left(\mathrm{~L}_{\mathrm{e}} / \mathrm{D}\right)+6.77\left(\mathrm{~L}_{\mathrm{f}} / \mathrm{D}\right)-162.45\left(\mathrm{~L}_{\mathrm{s}} / \mathrm{D}\right) \quad \text { For } \mathrm{L}_{\mathrm{e}} / \mathrm{L}<0.3
$$

Scatter plot for actual measured lateral capacity and predicted lateral capacity using Eqs. (9) and (10) are plotted and presented for Le/L greater than 0.30 and less than 0.30 in Figs. 12 and 13 respectively. The regression coefficient $\left(R^{2}\right)$ was obtained as 0.92 and 0.966 for Eqs. (9) and (10) respectively, which means that the predicted values of lateral pile capacity of socketed pile are very well agree with experimental values of socketed piles. It should be noted that the above equations were developed based the experimental test results (1-g) on model pile made of aluminium tube under low confining stress conditions in unsaturated cohesionless sand as top layer and concrete as bottom rock layer. Therefore, the application of the above equations is limited to the selected parameters. 


\title{
Conclusions
}

The lateral behaviour of socketed pile has been investigated in this paper by conducting 84 set of $1 \mathrm{~g}$ experimental studies on instrumented model pile having three different diameters of $25.4 \mathrm{~mm}, 38.1$ and $50.8 \mathrm{~mm}$ with varying depth of socketing from $0.5 \mathrm{D}$ to $3 \mathrm{D}$ with an increasing the order of $0.5 \mathrm{D}$. From the experimental studies the following conclusions are drawn.

1. The influence of the depth of socketing is significant only for $\mathrm{L}_{\mathrm{s}}$ greater than $2.0 \mathrm{D}$ in the case of Le/L ratio greater than 0.67 . However, the influence of the depth of socketing $\mathrm{L}_{\mathrm{s}}$ greater than $2.0 \mathrm{D}$ is dramatically increases the pile capacity in the case of $\mathrm{L}_{\mathrm{e}} / \mathrm{L}$ ratio less than 0.67 . From this observation, it is concluded that the depth of rock socketing is insignificant for the $\mathrm{L}_{\mathrm{e}} / \mathrm{L}$ ratio greater than 0.67 as for as lateral load capacity concern.

2. The pile diameters play a major role along with socketed depth in the lateral capacity of socketed piles. The lateral pile capacity is increased by 18 times when the pile is socketed with $3 \mathrm{D}$ in larger diameter $(50.8 \mathrm{~mm})$ pile for $\mathrm{L}_{\mathrm{e}} / \mathrm{L}$ ratio of 0.33 . From this observation, it is concluded that, the larger diameter piles (mono-piles) have greater lateral capacity under proper depth of socketing.

3. Based on the experimental results, empirical equations were developed to determine the allowable lateral capacity of the pile with respect to depth of rock socketing. These equations can be used to estimate the socketed pile lateral capacity with parameter limitations.

\begin{abstract}
List of symbols
$\varphi$ : Angle of internal friction; $C_{c}$ : Co-efficient of Curvature; $C_{u}$ : Co-efficient of Uniformity; D: Diameter of the pile; $D_{10}$ : Percentage of particle size finer than 10\%; $\mathrm{D}_{50}$ : Percentage of particle size finer than $50 \%$; DAS: Data acquisition system; $G_{s}$ : Specific Gravity; El: Flexural stiffness of pile; L: Length of pile; $L_{e}$ : Embedment length of pile in soil and hard stratum; $L_{f}$ : Free standing length of pile above the ground level; $L_{s}$ : Socketed length of pile in hard stratum; LVDT: Linearly varying differential transducer; $\mathrm{P}_{\mathrm{a}}$ : Allowable lateral load; $\mathrm{R}^{2}$ : Regression Co-efficient; $\mathrm{R}_{\mathrm{D}}$ : Relative Density Index; WoS: Without socketing.
\end{abstract}

\section{Authors' contributions}

ARP Carried out the experimental study, experimental data analysis and prepared the draft manuscript. KM developed the technical concept for the experimental study, corrected the experimental data and reviewed and finalized the manuscript. Both the authors read and approved the final manuscript.

\section{Competing interests}

The authors declare that they have no competing interests.

Received: 6 July 2020 Accepted: 6 January 2021

Published online: 20 April 2021

\section{References}

1. Begum NA, Sheethalakshmi P, Muthukkumaran K (2008) Lateral load capacity of single pile located at slope crest. Indian Geotech J 38(3):279-295

2. Begum NA, Muthukkumaran K (2009) Experimental investigation on single model pile in sloping ground under lateral load. Int J Geotechnical Eng 3(1):133-146

3. Broms BB (1964) Lateral resistance of piles in cohesion-less soils. J Soils Mech Found Div 90(2):27-63

4. Carter JP, Kulhawy FH (1992) Analysis of laterally loaded shafts in rock. Geotech Eng 118(6):839-855

5. Chandrasekaran SS, Boominathan A, Dodagoudar GR (2010) Group interaction effects on laterally loaded piles in clay. J Geotech Geo-environ Eng 136(4):573-582

6. Davisson MT, Robinson KE (1965) Bending and buckling of partially embedded piles. In: Proceedings of the 6 th international conference on soil mechanics and foundation engineering, vol 2, pp 243-246. 
7. Deendayal R, Muthukkumaran K, Sitharam TG (2016) Response of laterally loaded pile in soft clay on sloping ground. Int J Geotechnical Eng 10(1):10-22

8. Gandhi SR, Selvam S (1997) Group effect on driven piles under lateral load. J Geotech Geoenviron Eng 123(8):702-709

9. Garnier J, Gaudin C, Springman S et al (2007) Catalogue of scaling laws and similitude questions in geotechnical centrifuge modelling. Int J Phys Model Geotech 7(3):1-23

10. Haberfield C, Collingwood B (2006) Rock-socketed pile design and construction: a better way? Proc Instit Civil Eng Geotech Eng 159(3):207-217

11. IS $1498-2002$, Classification and identification of soils for general engineering purposes. Bureau of Indian Standards, New Delhi.

12. IS 2720 (Part 3/Sec-1) -2002, Methods of test for soils - determination of specific gravity for fine grained soils, Bureau of Indian Standards, New Delhi.

13. IS 2720 (Part 4) -2006, Methods of test for soils - grain size analysis, Bureau of Indian Standards, New Delhi.

14. IS 2720 (Part 13) -2002, Methods of test for soils - direct shear test, Bureau of Indian Standards, New Delhi.

15. Is 2720 (Part 14) -2002, Methods of test for soils-determination of density index of cohesionless soils, Bureau of Indian Standards, New Delhi

16. IS 14593-2003. Design and construction of bored cast-in-situ piles founded on rocks—guidelines. Bureau of Indian Standards, New Delhi

17. IS 2911 - Part 1/Section 4 - 2010, Design and construction of pile foundations_code of practice. Bureau of Indian Standards, New Delhi.

18. Jin-Jian C, Fan-Yun Z, Jian-Hua W, Lianyang Z (2017) Analysis of laterally loaded rock-socketed shafts considering the nonlinear behavior of both the soil/rock mass and the shaft. J Geotech Geoenviron Eng 143(3):06016025

19. Ke Y (2006) Analysis of laterally loaded drilled shafts in rock. PhD thesis, Univ of Akron

20. Liang R, Yang K, Nusairat J (2009) p-y Criterion for rock mass. J Geotech Geo-environ Eng 135(1):26-36

21. Muthukkumaran K, Sundaravadivelu R, Gandhi SR (2008) Effect of slope on p-y cures due to surcharge load. Soils Found 48(3):353-361

22. Muthukkumaran K (2014) Effect of slope and loading direction on laterally loaded piles in cohesionless soil. Int J Geomechanics 14(1):1-7

23. Muthukkumaran K, Almas Begum N (2015) Experimental investigation of single model pile subjected lateral load in sloping ground. Int J Geotech Geol Eng 33(4):935-946

24. Nandhagopal R, Muthukkumaran K (2020) Effect of rock-socketing on laterally loaded piles installed in the proximity of sloping ground. Int J Geomechanics. https://doi.org/10.1061/(ASCE)GM.1943-5622.0001895

25. Nunez IL (1988) Driving and tension loading of piles in sands on a centrifuge. In: Proceedings international conference 88, Paris, Corte J F (ed.), Balkema, Rotterdam, pp 353-362.

26. Prakash S, Kumar S (1996) Nonlinear lateral pile prediction in sand. J Geotech Eng 122(2):130-138

27. Reese LC (1997) Analysis of laterally loaded piles in weak rock. J Geotech Geo-environ Eng 123(11):1010-1017

28. Rezazadeh S, Eslami A (2017) Empirical methods for determining shaft bearing capacity of semi-deep foundations socketed in rocks. J Rock Mech Geotech Eng 9(2017):1140-1151

29. Singh AP, Bhandarib T, Ayothiraman R, SeshagiriRao K (2017) Numerical analysis of rock-socketed piles under combinedvertical-lateral loading. Procedia Eng 191(2017):776-784

30. Terzaghi K (1955) Evaluation of coefficients of subgrade reaction. Géotechnique 4:297-326

31. Zhang L, Ernst H, Einstein HH (2000) Nonlinear analysis of laterally loaded rock-socketed shafts. J Geotech Geoenviron Eng 126(11):955-968

\section{Publisher's Note}

Springer Nature remains neutral with regard to jurisdictional claims in published maps and institutional affiliations.

\section{Submit your manuscript to a SpringerOpen ${ }^{\circ}$ journal and benefit from:}

- Convenient online submission

- Rigorous peer review

- Open access: articles freely available online

- High visibility within the field

- Retaining the copyright to your article

Submit your next manuscript at $\gg$ springeropen.com 